University of Rhode Island

DigitalCommons@URI

The Rhode Island Current Conditions Index

Economics

$11-2009$

\title{
Rhode Island Current Conditions Index - November 2009
}

Leonard Lardaro

University of Rhode Island, lardaro@uri.edu

Follow this and additional works at: https://digitalcommons.uri.edu/ricci

Part of the Econometrics Commons

Terms of Use

All rights reserved under copyright.

\section{Recommended Citation}

Lardaro, Leonard, "Rhode Island Current Conditions Index - November 2009" (2009). The Rhode Island Current Conditions Index. Paper 47.

https://digitalcommons.uri.edu/ricci/47

This Article is brought to you for free and open access by the Economics at DigitalCommons@URI. It has been accepted for inclusion in The Rhode Island Current Conditions Index by an authorized administrator of DigitalCommons@URI.For more information, please contact digitalcommons-group@uri.edu. 


\section{GURRENT

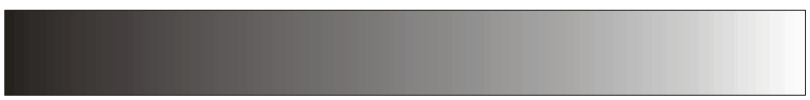

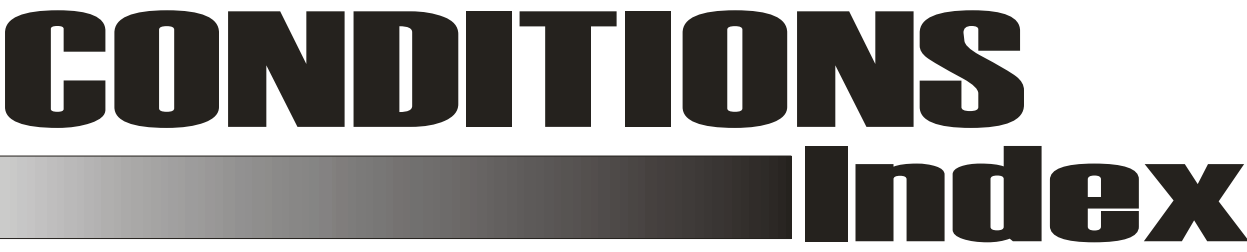
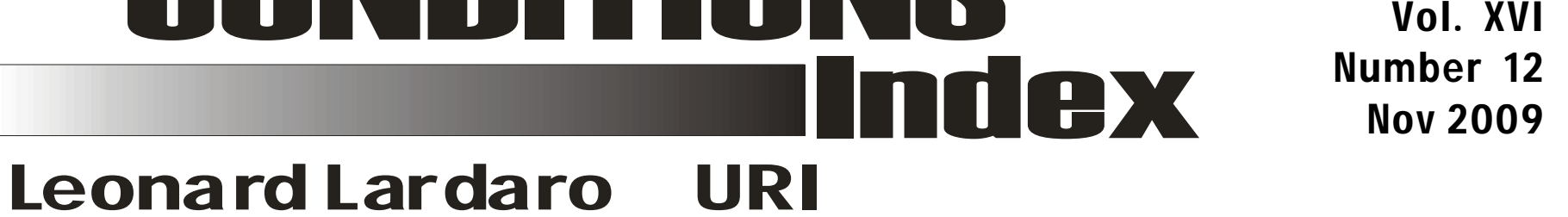

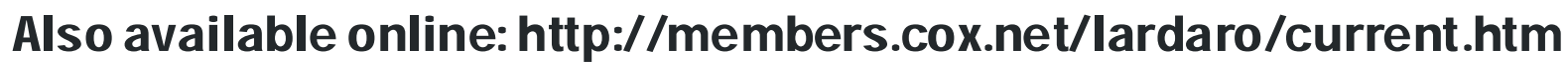

Rhode Island's economy reached a landmark in November. While still mired in a recession, for two and a half years at this point, the level of economic activity here improved again, this time moving to a neutral level, as the Current Conditions Index rose to 50. Compared to a year ago, six of the twelve $\mathrm{CCl}$ indicators improved. But not only did Rhode Island's economy fail to decline in November, the $\mathrm{CCl}$ beat its year-earlier value for the seventh consecutive month. In addition to this, eleven of the twelve $\mathrm{CCl}$ indicators either improved or were close to improving on a monthly basis.

Clearly, the course of Rhode Island's recession has continued to evolve from what we witnessed in 2008, the "recession from hell," into a the late stages of a "traditional" recession, based on $\mathrm{CCl}$ readings over the last seven months. DO NOT assume that our economy will continuously improve from here. As we move toward the end of this recession, expect

\begin{tabular}{|l|r|}
\hline \multicolumn{2}{|c|}{ CCI Indicators - \% Change } \\
\hline Government Employment & -2.2 \\
US Consumer Sentiment & 22.2 Y \\
\hline Single-Unit Permits & 67.2 Y \\
\hline Retail Sales & 6.4 Y \\
\hline Employment Services J obs & -10.2 \\
\hline Priv. Serv-Prod Employment & -3.2 \\
\hline Total Manufacturing Hours & -12.0 \\
\hline Manufacturing Wage & 2.9 Y \\
Labor Force & 0.6 Y \\
Benefit Exhaustions & 53.7 \\
\hline New Claims & $-21.43 \mathbf{~ Y}$ \\
Unemployment Rate & 39.6 \\
\hline \multicolumn{2}{|c|}{ Y= I mproved Value } \\
\hline
\end{tabular}

fluctuations in $\mathrm{CCl}$ values to continue, so that a sustained period of above-50 values, the hallmark of a recovery, will likely not begin for about four to six months (optimistically).

Focusing on the November $\mathrm{CCl}$ performance, there were six improving indicators, all of which displayed healthy changes. US Consumer Sentiment, our "star" performer of late, rose at a 22 percent again in November, its eighth consecutive year - over-year improvement. Retail Sales, one of the worse performing indicators of late, rose dramatically in November, by 6.4 percent, its first improvement in over a year. Our state's Labor Force continued its recent growth, rising by another 0.6 percent compared to a year ago. Growth in the Manufacturing Wage remained rapid in November, a 2.9 percent rate, tied for its most rapid rate of increase since July. The other two improving indicators are both leading indicators.
Single-Unit Permits, which measures new home construction, rose by 67.2 percent in November, but this growth rate was mainly the result of a relatively small number of permits a year ago. New home construction here has been virtually non-existent for all of this year. New Claims, which reflect layoffs, improved at an accelerating rate, falling by 21.4 percent compared to last November

In spite of the good news, there were several negatives this month. Future job prospects based on Employment Service Jobs, another leading indicator, remained discouraging, as these fell 10.2 percent compared to a year ago. In spite of this decline, this indicator appears to have stabilized on a monthly basis since March of this year. Total Manufacturing Hours fell again at a double-digit rate, declining by 12 percent in November, as both employment and the workweek fell. While Rhode Island's manufacturing sector continues to weaken relative to this sector nationally, on a monthly basis at least, it appears that the decline here may be moderating. Private Service-Producing Employment fell again at a rate in excess of 3 percent (by $3.2 \%$ ), reflecting the grim job prospects here. Government Employment, driven largely by budget woes, declined by 2.2 percent in November, a more rapid decline than the past two months. Finally, Benefit Exhaustions, which reflects long-term unemployment, surged again in November, this time by just under 54 percent, while our state's Unemployment Rate fell from October but was significantly higher than a year ago $(12.7 \%$ vs. $9.1 \%)$.

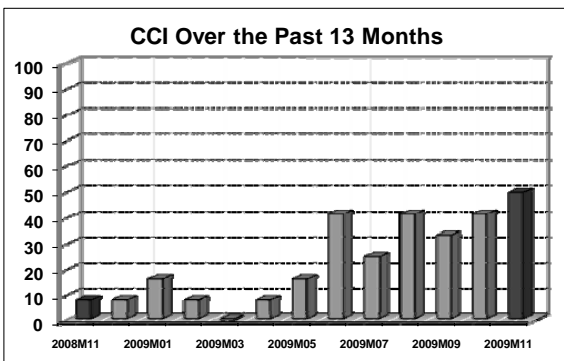

\section{THE BOTTOM LINE}

Rhode Island has been through a lot in the two and a half years it has been in recession. Following the economic freefall in late 2008, we continue to fight our way back toward positive growth. The first step was more slowly declining activity. The second step, accomplished this month, was re-establishing a neutral $\mathrm{CCl}$ value. Hopefully we will register above- 50 values in the early part of 2010, signaling the beginning of a recovery.

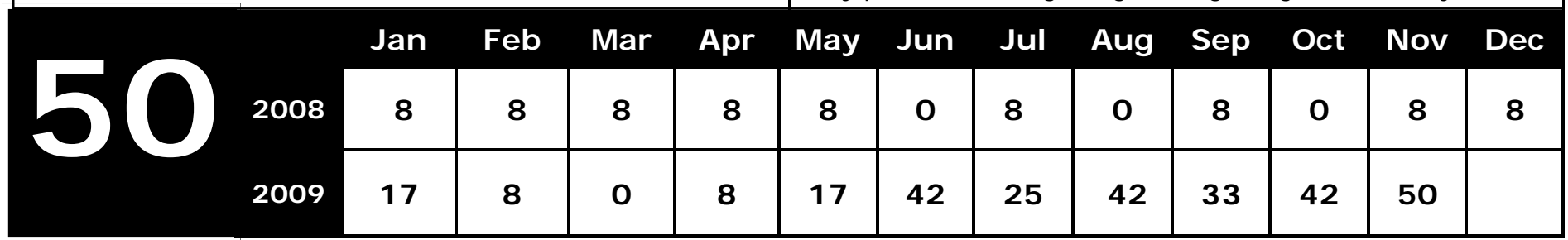

